\title{
'Eating at us': Representations of knowledge in the activist documentary film Food, Inc.
}

RICK FLOWERS AND ELAINE SWAN

University of Technology, Sydney, Australia

\begin{abstract}
Writing on social movement learning and environmental adult education invokes particular views on knowledge that need further examination and development in relation to food social movements. Although food social movements take different forms, the paper argues that the politics of food knowledge is at the centre of many of these movements. Contributing to the discourse of social movement learning, this article focuses on the film Food, Inc., an important activist resource and documentary film about a particular food movement. We analyse how it legitimates certain forms of knowledge about food production and consumption and de-legitimates others. Whilst a useful case study on knowledge and film activism in itself, the article seeks to challenge what it sees as some key tenets about knowledge in social movement learning literature. One key tenet is that it is self-evident whose interests are served by 'ordinary people's knowledge' and 'scientific knowledge.' Instead, it is argued that when it comes to collective action for food there is ambiguity, messiness and contestation about what constitutes knowledge and, in particular, anti-capitalist knowledge. But realisation of such ambiguity, messiness and contestation should not lead to paralysed inaction, but to informed and nuanced action. A question then for social movement learning practitioners is how they can mobilise social change through a broader sense of knowledge and its effects.
\end{abstract}

\section{Keywords:}

food social movements, social movement learning, film, popular education, food knowledges, documentary activism

\section{Introduction}

Drawing on a larger research project on sustainable and healthy food and consumer learning in Australia (Flowers and Swan, 2010), this article examines the construction of 'knowledge' in food social movements through an analysis of the film, Food, Inc. 
In so doing, we seek to contribute to theory-building in social movement learning by focusing on knowledge as opposed to learning. Recent writing has emphasised that social movements generate knowledge (Crowther and Shaw 1997; Clover and Hall 2000; Hall and Clover 2005; Walters 2005; Crowther et al. 2008; Flowers and Chodkiewicz 2009; Flowers, Guevara and Whelan 2009; Sandlin and Walter 2.009; Choudry and Kapoor 2010; Scandrett et al. 2010). This has become somewhat of an unexamined aphorism and by this we mean two things. Firstly, it is the idea that social movements enable what is called 'knowledge generation' which is rarely expounded by writers on social movement learning. We recognise that literature on environmental adult education often refers to pedagogical processes such as performative: dialogue and also knowledge problematising processes. We ask what kinds of knowledge are generated? How and where does knowledge come from, and what is its status and value? We agree that social movements do generate new knowledge, but not in a cultural or social vacuum. Hence, our particular take is that they also draw on a panoply of official, legitimate, unofficial, illegitimate and contradictory knowledges (Birchall, 2006). We argue that social movements not only generate knowledge but also maintain, bastardise and transform knowledge of varying kinds; and not all of these are progressive. This is because ecological movements are often more conservative than progressive, particularly outside Europe. The politics of this has been underexplored.

While there is a growing literature on social movement learning, little of this focuses on 'food social movements' (see Hall, 2004 and Cook, 2009 for exceptions). The term food social movements is a recent term, coming out of ideas from new social movement theorising that emerged in the late 1980s, and is used to denote a whole range of political practices around organic foods, local foods, anti-industrialised food production, vegetarianism, food for social justice, slow food movement, food security, to name but a few. We know that some of these practices have been around for a long time but were not named as social movements. One can go back, for example, to the counter-cuisine movement of the 1960s in California (Belasco, 2007) and, as with other new social movements, food social movements go beyond campaigns to include initiatives such as community gardens, farmers' markets, food education, and documentary films. Food has become a battleground for politics, policy, reform and education in recent years. This is important for educators because how we (all living creatures) eat, and what we eat, are at the centre of what we want to be and how we want the world to be (Galusky, 2010). In essence, food social movements seek to get us to change what and how we eat: this includes our food production, consumption, preparation, cooking and eating habits.

We use the term 'food knowledges' to get at a wide range of understandings and practices that permeate how we think about and use food. This range includes: knowledges which are codified and informal; academic and experiential; lay and expert; embodied and cognitive; individual and institutional; emotional and logical; everyday and rarefied; gendered, racialised and classed. Our understanding of food knowledges draws on literatures from a range of disciplines including: geography, anthropology, history, environmental science, feminist studies and cultural studies.

Our focus is on knowledge, rather than learning, as there is much more to be said about the former and the relationship between knowledge and learning is complex. We seek to analyse how social movement learning theorists have thought about knowledge in relation to food social movements in particular. We do not wish to 
essentialise learning or knowledge or presume some overarching self-evident link. We observe that it is widely assumed in social movement learning theory and environmental adult education that bottom-up knowledge is marginalised and in need of recognition, respect and validation; and expert or canonical knowledge is too overweening in some forms of environmental education and should be treated with suspicion and resistance. Our own view is to understand the links between learning and knowledge by thinking more about knowledge. Social movements have for some time been seen as bearers of knowledge on a range of issues such as injustice, politics, grievances, social divisions and power structures and the power of science and technology (Chesters and Welsh, 2011: 105). But social movements are now also seen as producers of knowledge (ibid.): thus, the term 'knowledge generation' is often used in social movement learning theories to get at this shift.

The politics of knowing, what is known, who produces it and 'who is in the know' are critical to food social movements. Many different groups - policy makers, churches, advocacy groups, schools, chefs, think we don't know enough about our food (Short, 2006; Kimura, 2010). For example, knowledge about what and how to cook is imagined to be on the decline amongst 'modern' mothers and children and subject to much policy and media commentary. Scientific knowledge in the service of corporations - whether in relation to GM foods or industrialisation of foodstuffs - is constructed as 'bad' knowledge. In the slow food movement, socalled traditional ways of knowing what to grow and cook are imagined to hold the key to improving our food lives. In 'foodie' discourse, good 'taste' is associated with caring about certain classed and racialised 'food knowledge' (Johnston and Baumann, 2010). In the 'locavore' food movement, knowing who made your food and where it hails from, what Cook and Crang (1996) call 'geographical knowledges', is a political imperative. Knowing about food is imagined to change us into more ethical eaters and shoppers (ibid.). To be a better food citizen, we need to be better knowers. Of course in all of this, there is a classed, racialised and gendered politics to who is seen as in need of knowledge and who is set up as 'in the know' (Clover, Follen and Hall, 2000).

To start to examine food-social-movement knowledges we analyse the film Food, Inc. We do so on a number of counts. Firstly, it is not just through social movement groups that knowledge is reproduced and circulated. As Nisbet and Aufderheide (2009: 450) write, films are 'considered part of a larger effort to spark debate, mould public opinion, shape policy, and build activist networks'. They can have impact on community organisations, policy makers, corporations and educators (Whiteman, 2010). Secondly, film embodies a growing genre of public pedagogy about food. The film is part of a wider social action project, including educational resources, an edited book, webpage, facebook site, toolkit and blogs. Thirdly, the film solidifies in celluloid what is often referred to as 'knowledge generation' in social movements and because it offers one site in which we can see knowledges portrayed, we can analyse these forms of knowledge closely.

We begin with an overview of representations of knowledge in recent writing on social movement learning, environmental adult and popular education. We then turn to the different ways in which knowledge has been discussed in recent social theory and in particular in food studies; this is followed by a brief methodological section, an introduction to the film Food, Inc., and an analysis of some of the knowledge themes in the film Food, Inc. 


\section{Social movement learning and knowledge}

In this section we consider the ways in which several leading theorists describe and discuss knowledge in social movements. Our purpose here is not to review debates about epistemological positions but to illustrate in what ways the concept of knowledge is defined and used. We start first with social movement learning literature and then move to environmental adult education.

For our first example, we take a recent paper by Hall (2006) who mentions the knowledge-generating capacities of social movements but then focuses his discussion on how we can understand learning in social movements. The result is that attention is directed away from knowledge. He refers to the 'catalytic power of learning and its sister activity, knowledge creation' (Hall, 2009: 46) and argues rightly that these have been under-theorised, but, again, he focuses his attention on learning, except for a brief reference to what he calls non-dominant forms of knowledge from Indigenous people and women. These moves - to invoke knowledge and then to focus on learining and to refer approvingly to marginalised knowledge - are common in popular education theorising about social movements.

Another example is in a paper by Walters (2005). She cites an important quote from Eyerman and Jamison (1991): 'social movements are not merely social dramas; they are the social action from where new knowledge including worldviews, ideologies, religious and scientific theories originate' (1991: 14, cited in 2005: 55). This starts to unpack the types of knowledges that may be 'generated' in social movements, but again for the rest of the paper, Walter's focus turns to learning rather than knowledge. She suggests that part of the knowledge generation process involves day-to-day social movement activities. This is helpful but it creates an effect of making social movements seem like hermetically sealed containers; even the word generation itself reproduces this view that the origin of knowledge is somehow in the confines of the social movement.

Theorists (for example, Crowther and Shaw, 1993) write forcefully about what they see as better forms of social movement knowledge which invokes a hierarchy where so-called grassroots knowledge is at the top and dominant knowledge is at the bottom. This theme is further developed in a recently edited book, the aim of which is to recognise 'the conceptual resources and knowledge produced in people's collective struggles against injustice' (Choudry and Kapoor, 2010: 2). The book's purpose is to 'articulate and document knowledge production, informal learning and education work' (2010: 2), particularly focusing on 'epistemologies of knowledge colonialism and imperialism' (ibid.: 3). This is important work but we see a typical move in the literature in which knowledge from the so-called 'bottom-up' is validated in and of itself, without much critical evaluation of the content of this knowledge.

In environmental adult education literature, there is a tradition of a more sustained discussion on knowledge. This mainly takes the form of identifying the value of marginalised knowledge, outlining more progressive pedagogical processes that 'reveal' or generate marginalised knowledge and a critique of dominant knowledges, in particular science. Clover and Hall write that 'environmental adult education represents a movement away from expert information-driven paradigm of much public environmental education towards the idea of political empowerment, people's knowledge, and collective action for change' (2009: 163). Experiential knowledge from marginalised groups e.g. women, working class people, indigenous people is 
one important yet often ignored form of knowledge (Clover,2004; Clover and Hall, 2009). This kind of knowledge can be seen as complex and, at times, based on dailylived experience which can provide a counter-hegemonic knowledge base (Malone, $2003 \mathrm{a}, \mathrm{b}$ ). We agree with these points, but refine them further by outlining how complex this area is and how sometimes, people are muddle-headed, contradictory and reactionary. Feminist standpoint theorists have argued against the romanticisation of the idea that experiential knowledge is unmediated or intrinsically radical, Our second point on this is that it can lead to the assertion that only certain pedagogical processes are legitimate: thus, transmission methods such as information transfer, sharing expertise and 'telling people' are not seen as the most productive knowledge processes. Finally, science itself might be seen to be a homogenously bad form of knowledge circulated by 'knowledge experts or canonists' (Hill, 2003). For example, Hill argues that activist educators need to challenge the 'scientific establishment' and 'scientific truth claims' (2003: 32). As we discuss below, science is not monolithic but rather an internally contested, multi-disciplinary set of ideas. We agree with Clover, Follen and Hall (2000) that experiential knowledge and marginalised 'knowing subjects' are important and are often misrepresented or dismissed. Our point is that we need to relativise all forms of knowledge.

In summary, the effect of the moves we outline above is that adult education theorists tend to portray social movements as sites of mostly positive and rich learning (Hall and Clover, 2005). We share the desire to enable people with histories of exclusion to have more control of learning and knowledge production, yet, we think this argument can be augmented by focusing more on specificities about types and impact of knowledges that are produced. It is important to interrogate what and how knowledge is produced. We do value the ongoing project of supporting marginalised groups to have more of what we might call 'knowledge-power', but think this can be advanced by closer theorising about the nature of knowledge.

What is missing for us is a means to analyse the multi-dimensional, desirable along with the undesirable, zealous and ambivalent nature of knowledge-generation that takes place in social movements. To start to elaborate some of this, we now turn to recent debates in social theory on knowledge which can offer us a wider set of concepts and analytical resources.

\section{Knowledges}

In this next section we survey a range of different approaches to theorising knowledge. Our first point is that we can turn to other fields such as organisational theory, sociology, feminism and cultural studies to theorise new ways about knowledge in social movements. Most of these theorists emphasise the plurality of knowledges in contemporary culture (Goldblatt, 2000: 1). Thus just for starters, there is scientific, religious, expert forms of, common sense, and cultural knowledges (Hincliffe and Woodward, 2004) Another attempt to map some of this diversity comes from cultural theorists, Birchall (2006), for example, whose work on 'popular knowledges' extends the idea of knowledge to include gossip, conspiracy theories and alien abduction narratives. In her mapping of different knowledges from grassroots know-how to common sense, ideology, useful knowledge, humanism, she comes up with what she calls a 'knowledge-scape': this includes official, legitimate, illegitimate, Indigenous, and popular, knowledge. Her key argument is that different forms of illegitimate knowledge 
challenge our ideas of what constitutes knowledge itself. We know that social movement learning theorists point out that bottom up knowledge is important and that there is a plurality of knowledge but these literatures are important because they can help social movement learning theorists start to typologise the multiple forms of knowledge in any context. This is important as it refines the discussion and moves it away from simple binaries of dominant and lay knowledge.

There is a growing literature on knowledge in food social movements. For example, a large project in Europe undertaken across ten countries on sustainable food has emphasised the typology of different knowledges and the related, specific practices, of knowledge use (Csurgo et al. 2008; Fonte, 2008). This typology includes scientific knowledge from researchers; political and managerial knowledge from project officers and 'local knowledge' from rural producers. Not only does this literature set out the different types of knowledges but it also stresses the interactions - the 'knowledge dynamics' (Fonte, 2008) between scientific, managerial and lay knowledge in food social movements. The research shows how new combinations of lay and expert knowledge is being produced. This finding breaks down the simplistic binary of laygood / expert-bad sometimes invoked in social movement learning and environmental adult education. Building on this work, Fonte shows how local knowers started to be seen as experts and started to circulate their knowledge through what she calls informal science networks. Thus again, Fonte is showing us that there are different forms of science and that science isn't always the 'baddie'. All these writers emphasise the politics and power of the dynamics of knowledge capital in food movements (Csurgo et al. 2008). Thus, in our work we should attend to dynamics much more, tracking knowledges over time, rather than assuming that we know already how knowledge works.

An important related argument for our paper is that much of what is going on in food social movements is 'struggles over knowledge systems' (Goodman and Du'Puis, 2002). Again this word 'system' encourages us to look beyond the confines of one activist group or social movement to examine how knowledge is generated, circulated and recycled. An example of a site of struggle, for Goodman and DuPuis, is the new knowledge systems in the growing of food. Their main argument is that in the analysis of food production, consumption and knowledge we should not privilege producer over consumer knowledge. This is important as it reminds us to break down the category of 'ordinary people'. In some food activism, farmers are seen as the privileged experiential knowers. So Goodman and DuPuis write, 'how the consumer goes about knowing food is just as important as farmers' knowledge networks in the creation of an alternative food system' (2002: 15). For them, consumers' right to know about their food is central to social movements. In addition, they stress how new knowledges in food produce new figures and types of subjectivity, for example, 'discerning food consumers' and 'cosmopolitan consumers' that circulate in different discourses on food and knowledge (ibid.:8). We think that these new types of subjectivity and the way they are generated are under-explored in theorising about social movement learning and can help us think about breaking down the category of 'ordinary people'.

\section{Scientific knowledge}

Science is a key form of knowledge in food social movements, the film Food, Inc. and in writing on environmental adult education. Of course we should be wary, as many food activists are, of corporate interests being promoted by particular versions of 
scientific knowledge. But again it is important to recognize that scientific knowledge itself comes in different versions: medical, biological, psychological, chemical etc. As Goodman et al. write, 'Just beneath the thin yet oft-authoritative veneer of "crisp" science and eco-political discourses are variegated, messy and contentious interactions of knowledge, power and ideology', in which facts and values and interpretations are all debated (2008: 5). This argument destabilises the simple term 'knowledge generation' in that it shows us the layers and temporalities that are part of knowledge generation.

We agree with Ross (1991) who asserts that science should not simply be dismissed tout court as necessarily being the handmaiden of corporations. He cites the wellknown feminist thinker on science and culture, Haraway, that science has the prospect of providing 'better accounts of the world' that in his words 'will be publicly answerable and of service to progressive interests' (1991: 29). Working with Ross' suggestion, we can see how Haraway's work on science can help us think through the knowledge politics of science in more nuanced ways. Myerson (2000) explains how Haraway, in her book Modest Witness (1996), is more welcoming of 'technoscience' than many on the left might expect. Although not a 'fan of Monsanto and other gene genies', she writes: 'I find myself especially drawn by such engaging new beings as the tomato with a gene from a cold-sea-bottom-living flounder' (cited in Myerson 2000: 6). These things, in Myerson's view, are 'neither natural nor unnatural, in the old senses: they are beyond natural and unnatural'. As he writes, 'there was never a nature in which all the categories were pure' (ibid.: 37) therefore 'we can no longer talk with confidence about 'nature' or 'culture' (ibid.: 62). This raises questions about how nature is invoked in food social movements, and the film Food, Inc.

Myserson is keen to emphasise that Haraway is not celebrating hyper-capitalism and 'corporate biology', what she refers to as 'the New World Order, Inc'. She sees herself as an activist but is cautious about 'any demand for a return to a lost purity' (ibid: 32). For example, she is critical of the idea of impurity being used by anti-genetic food activists in their arguments. Haraway writes, 'it is a mistake in this context to forget that anxieties over the pollution of lineages is at the origin of racist discourse in European cultures' (ibid.: 35). This work asks us to think hard about what we romanticise or see as authentic or real.

This does not mean that Haraway is not critical of science. For her science has a 'truly stunning power' to establish matters of fact but 'facts are perpetually in doubt' (ibid.: 40). 'This is because genetic facts include 'a whole calculus of what might and might not happen' (ibid.: 48). The reason we include this discussion is that it helps us start to problematise the specifics of knowledge generation and its relation to expert knowledge. It provides new vocabularies for rebutting the power of certain kinds of expertise but in ways that go beyond simply reaffirming lay knowledge as intrinsically better. Haraway's work on science in particular is important because she is an activist and is interested in social change and offers us more nuanced ways of theorising the politics of science and its relationship to social action.

\section{Food knowledges}

We now turn to ideas about knowledge in food studies. We provide a brief survey of three different types of food studies theorist: David Sutton, an anthropologist; Francis Short, a sociologist and Ann Vileisis, an historian. 
Sutton's work on food focuses on what he calls the 'doing/learning' of cooking through an ethnographic study in Greece. He argues that cooking involves an 'embodied apprenticeship' involving cognitive and embodied memory as forms of knowledges. This, for Sutton, is not about remembering a set of rules but involves 'images, tastes, smells and experiences, techniques that can only be partially articulated, or memory-jogged, through the medium of recipes' (2001: 135). In particular, he is interested in understanding how intergenerational, embodied cooking knowledge, has been replaced by cookbooks, recipes and the introduction of processed foods. The nature of his argument brings out the importance of the sensuousness of knowledge in food production and consumption. This then takes the idea of experiential lay knowledge and starts to analyse it in close detail, affirming its embodied nature.

Another study of food knowledge comes from Short's (2006) work on new food technologies and industrialised foods. Her overall view is that cooking in the home does not operate along dichotomies of 'real and traditional skills versus artificial, technologically reliant and unskilled' (ibid.: 113). She argues that 'cooking today means a heterogeneous mix of the fresh, the raw and the pre-prepared, the new and the traditional, the technological and the manual' (ibid.: 114). She shows us how cooking knowledge involves technical skills but also 'tacit skills of perception, conception and planning' (ibid.: 117). For her, food knowledge is more multi-faceted than many suggest.

From an historical perspective, Vileisis (2004) argues that Americans know little about their food. She claims that 'two hundred years ago, most Americans knew a lot more about what they ate in a direct, first-hand, rooted-in-the-ground way because most had a hand in growing a sizable share of their foods' (2004: 4). At the centre of this is knowing the place of origin of food. She argues that as food production industrialised in the 19th century, people imagined that their senses - sight, smell, taste and touch - which provided knowledge about food - were taken over by food science. She refers to this process as the 'denaturing the senses' (ibid.: 74) which can lead to a nostalgia for rural knowledge and nature primarily among the middle classes. The countryside was associated with the natural and the pure in contrast to the city and connotations of culture, synthetic and the polluted. City foods were starting to be seen as not natural.

The point in understanding how the notion of 'natural food' has arisen is to dereify it. We suggest that social movement learning theorists could likewise problematise notions of knowledge we have widely used such as local, lay, people's, globall, scientific and corporate. In the case of 'natural food' we think there is a risk in creating misleading and romanticised ideals that neglect to mention the huge advances in food safety, and capacity to save time preparing food.

\section{Food, Inc.}

This is an American documentary film, released in 2008, which undertakes a critique of the global capitalist food system. It is directed by film-maker Robert Kenner, and is narrated by food activists, journalists and best-selling authors Michael Pollan who wrote Omnivore's Dilemma (2006) and Eric Schlosser, who wrote Fast Food Nation. The film, which has high-production values, covers a range of issues: diabetes, factory farming, genetic modification, worker exploitation, pesticides and the domination of food production by big corporations. These are organised in what the film calls 
'chapters' and made up of cartoons, interviews, personal experience stories, documentary footage, and animations. One of the most important interviewees in the film is Joel Salatin, who on the international speaking circuit is often presented as the 'world's most recognised beyond organic and clean food farmer'. The circulation and enthusiastic reception of the film in 'progressive' circles has been so wide as to provoke an alliance of associations that represent the livestock, meat and poultry industries in the USA to launch a website to counter what they claim are the myths propagated in the film (SafeFoodInc.com, 2011). It might be argued that using the film Food, Inc. as our lens on knowledge in social movement learning is a flimsy one on which to make an argument. We think it is an important focus for an initial exploration on three counts: first, films are increasingly prevalent forms of social activism that are distributed as such and relatively under-researched (Lindenfeld, 2010); second, their use of knowledge is easier to analyse than the day to day activities of a social group; third, Food, Inc. has had a tangible impact on what kinds of knowledge are seen to be important to food activism.

\section{Methodology}

Film analysis can be done in various ways. Different conceptual frameworks and methodologies come from different disciplines (Sturken and Cartwright, 2001; Rose 2007). One film theorist, Iedema, for example, mentions a number of potential approaches: thematic, 'auteur'-centred, psycho-analytical or symptomatic, structuralist and semiotic perspectives' (2001 : 186). Drawing on his work, our analysis is informed by what has been called 'social semiotics' which is concerned with 'political understandings, the reading positions and the practical possibilities which analysis make possible' (ibid. 186). Visual cultural theorists suggest three lenses for analysis: the images, their production and how they circulate, and their reception by audiences and their 'practices of looking' (Sturken and Cartwright 2001; Rose 2007). We focus on the film's 'representation processes' through the formal filmic properties of Food, Inc.: thus, we are examining how the film shows knowledges rather than how the film is consumed or produced (Johnson, 1986).

To analyse knowledge in social movements it is, of course, important to focus on presentations, i.e. 'real' people engaged in 'real' action. But likewise, and in the light of increasing reliance on texts, social movement learning theorists should pay attention to re-presentations through films, websites, posters etc that include reconstructions of people, ideas and ideologies. This is because images construct the possibilities for a particular kind of (reading) through the nature of style, content, layout, etc. (Swan, 2010). Images do this by circumscribing the 'point of view' and the 'meaning potential' (Jewitt and Oyama, 2001: 135) through their formal material properties. Many of these formal qualities work at a connotative level, representing broader concepts, values, ideologies related to cultural trends and links to discourses prevalent in culture (van Leeuwen, 2001). This means, according to van Leeuwen, that we need to understand how the images represent what they do; in particular, we need to get at what ideas and values do the people, places and things represented by images stand for? What is it that allows the images to associate in particular ways? Our analysis stayed then at the site of the film and its formal composition.

Our analysis is not looking at how the film circulated, the range of economic, social and political relations, institutions and practices that surrounded the film, or the film's 
reception by audiences and their ' practices of looking' (Sturken and Cartwright, 2001; Rose 2007). It is important to note that audiences may read films in different ways: they may read against the grain. These other forms of analysis are therefore important but they relate to different research purposes. Our aim was to examine how an influential film represented food knowledges. There is only so much meaning that can potentially be read into a film by audiences because as social semiotics makes clear films set up preferred modes of reading and meaning potential through their composition material filmic qualities.

Having watched the film through once, we produced a 'multi-modal' analytical framework drawn from the work of film theorists Iedema (2001) and van Leeuwen (2001). Their work is influenced by social semiotics and attempts to provide a rnicro technical analytical framework focused on filmic formal properties but holds on to a bigger-picture political critique too. Based on their work, we structured the framework to include formal properties of the film's representational strategies including soundtrack, verbal and speech track, angle types, film sequence, scene lengths, use of time and key actors, locations and actions (Iedema 2001). Having read a number of film and visual analysis texts, and watched the film through once, we produced a written 'template' based on a number of filmic formal properties covering different material characteristics of the film. We then organised the template into three core themes each divided into sub-sections. Thus, we examined the film's verbal, musical and visual representational tecbniques which produce what the film can be said to be about; we analysed the orientation the film sets up through its camera angles, close ups, distances. Orientation is about how we as viewers are encouraged to relate to different people and objects in the film; how objects and people are being positioned through camera techniques. We also examined the organisation of the: film in terms of its structure, rhythms, genres and integration of different elements. The organisation of the film produces the 'argument structure', how the film persuades us through the unfolding of narratives, time, scene lengths etc.

We developed our framework by focusing a number of questions under each of the headings: for example, under the heading of representation, we asked what sort of music is played at particular times; what sorts of sounds and noises do we hear; what kind of verbal and speech track is played; is there a narrator and what kind of narrator are they; what are the key types of action that we see; do we see people eating? What kind of food do we see? What kinds of settings do we see: factories, offices, farms, restaurants etc? What kinds of frames and editing? What kind of shots and angles are used to show different people and foods? What kind of people do we see? What do they look like? What clothes do they wear? What genders, ethnicities, ages, classes are represented and how?

We were particularly interested in detailed analysis of 'people with knowledge' in the film. This focused our attention on what kinds of scientists were being, represented - biologists, pharmacists etc, what were they doing, how were they being positioned - as benign or threatening - how was science being set up - as progressive or destructive?

We were concerned with using the framework to break down the meanings in the film and we used literature on food knowledges to start our analysis: examining how nature and science were represented, how experts and lay people were seen. We are not able to write up a fuller description of our analysis in this paper and so presient a thematic discussion. 


\section{Discussion}

In essence, the film is using knowledge as a resource to expose viewers to 'truths' about food production. In line with this, one of the dominant tropes in the film is that of things being hidden from us, the 'veil' of secrecy being lifted off food production. By informing us, the film seeks to turn us from relatively ignorant viewers into food social activists. Isomorphic with this overarching aim, the film is made up of a number of mini activist-conversion narratives in which 'ordinary' people are shown as not knowing much about food, becoming more knowledgeable, and as a result becoming food activists. This constitutes a point of identification for the viewer.

The various knowledges the film draws on include scientific and lay knowledges as discussed in our review of the literature above. But using Birchall's extended notion of what constitutes knowledge we can also see scientific, experiential, legal, nutritional, labour rights, journalistic, pseudoscience, farming and food production knowledges. This emphasises our point that we need to unpack what we mean when we invoke the term knowledge in social movement learning. Science itself comes in different forms from experts: the celebrity farmer, Joel Salatin, and Richard Lobbs, chair of the US National Chicken Council. More specifically in this film; animal biology, food technology, nutritional knowledges are just three drawn upon at different moments. So when we talk about science and 'knowledge generation' in social movements, we can start to see how we need to examine the form and content of knowledges and the dynamics and hierarchies between them.

Unsurprisingly, given that this is an activist film the global capitalist food industrial system, knowledge about science and nature are key. But nature has many meanings. As Soper explains:

Nature is both machine and organism, passive matter and vitalist agency. It is represented as savage and noble, polluted and wholesome, lewd and innocent, carnal and pure, chaotic and ordered... a source of sensual delight, a nurturing bosom, a site of treacherous and vindictive forces (1995: 71).

In line with this, the film begins with a juxtaposition between what we might call 'farming nature' and 'supermarket nature.' The viewer sees a white, male farmer on a horse in the opening scene and this scene is transmogrified into a label on a piece of butter on a supermarket shelf. Salatin presents farming nature as more pure than supermarket nature. Supermarkets are constructed as corporate inventions that have de-natured nature. In the film, Salatin is shown at home on the range - 'in nature'. He is someone with the right kind of knowledge about nature to challenge the corporate denaturing of food. Franklin argues that the green movement tends to 'skew... in favour of a highly selected subset of natures' (2002: 5). In Food, Inc., the subset of nature privileged is nature as resource which is represented as protected but utilised by certain types of farming and food production. This is not wild nature, nor it is urban nature but somewhere in between: a resource which needs to be delicately managed.

In Food, Inc., small farming nature is polarised with big, urban, industrialised corporations. Sunlit scenes of farmers and farmland are contrasted with dark scenes of food corporations as satanic mills and food industrialists, when indoors, are surrounded by technology and computers. Nature, for European writers of the romantic literary tradition was a therapeutic space for rejuvenating away from modernity. In 
similar vein for Salatin, nature is what Guthman calls a pre-political space (2004). He presents his small farm as a place of resistance, as a particular sort of ethical space. Animals can be cared for but still eaten. Non-white workers on his farm work out of doors but do not speak in the film.

Science is a complex cultural category as our review on knowledges suggests. Writers (Weingart, Muhl and Pansegrau, 2003) on representations of science in film suggest that we need to attend to which disciplines are visualised. In Food, Inc., it is food-technology that is most clearly represented. There are scenes of laboratories and a food chemist animatedly discussing new developments. At one point he is shown, in his white coat, with his arm feeling the insides of a live cow's stomach through a white plastic ring in its side. This is not quite science producing Frankenstein foods and science in the service of corporations being used for nefarious ends. Through the images and commentary, industrial food is presented as 'de-natured' (Vileisis, 2004). Farmers are imagined as putting the nature back into food. They are shown out of the laboratory in sunlit fields as closer to 'nature'. Their knowledge of nature is presented as offering a better form of food production.

At the same time, science in some of its forms as a knowledge isn't simply being rejected. Salatin and Pollan draw on a range of scientific discourses on food to make their arguments. They present some scientific facts as undisputed. At one point in the film, Pollan draws on a highly debatable 'fact' from evolutionary biology. He says 'when you engineer foods you are pressing our evolutionary buttons... we are hardwired to three tastes - salt, fat and sugar ... these things are very rare in nature.' There is no discussion of this 'fact' and yet it is central to the film's presentation of what we are 'naturally' and how food science is interfering with this authentic way of being human. Another example is when Schlosser claims 'food poisoning is getting worse when you'd think it could be safer with all the technology at our disposal.' But various studies (e.g. Grunert, 2005) show that overall, food safety has enjoyed improvements over the last 100 years. Taking bread as an example, it was common practice in European and North American countries in the 19th and early 20th centuries for bakers to include sawdust and other unhealthy additives in their loaves. Food safety regulations were introduced to stop this (Collins 1993). These examples are shown as solid, undisputable forms of authoritative knowledge, rather than as something more ambiguous.

Our final point is about the caricatures of knowers. Goodman and Dupuis reinforce that knowledges in food activism produce figures: for example the 'discerning food consumers' and the 'cosmopolitan consumers' (2002: 8). In Food, Inc. we are shown 'the good knower': people who have the right knowledge about food. These are not animal rights activists or environmentalists. They are not even consumers or women who cook and shop as Sutton (2001) and Short (2006) might point to. Those in the know are the triumvirate of Salatin the farmer, Schlosser and Pollan, the journalists. As Ramsey (2010) writes we are shown the testimonies of 'bankrupt family farmers, debt-wracked chicken warehouse contractors, Mexican immigrant meat packers, food chemists and food consumers' (p. 258). But these are presented as people who need to be helped with the right knowledge. Our literature review also pointed to the rise of a number of qualitative studies in food studies which focus on cooking and consumption knowledges, often seen as women's knowledges. The film largely ignores these. Thus, it concentrates on what Goodman and DuPuis (2002) call 'pro- 
duction knowledge' and in particular valorises white, male and celebrity farmer and journalist knowledge.

We now want to explain why we find it problematic that in Food, Inc. people are presented as caricatures. We see businessmen in suits and briefcases striding across a wheat field towards a factory belching dirty smoke from towering chimney stacks. We only see their backs. They are the faceless bureaucrats or bosses who will not let us see all the gruesome details of food production. In another film scene we are able to follow a Hispanic family - mother, father and two teenage kids. We see them all eating McDonalds burgers in their family car, on the way to school and work. Mother says she didn't know that there were unsafe foods and is presented as the problematic knower. We see them in a fruit and vegetable shop. Father says, 'look at the broccoli; too expensive, man.' The family asserts that a McDonalds meal provides much better value-for-money than buying and preparing their own meal at home.

It is problematic that the film Food, Inc. relies on caricatures because it does not give activists much to work with. This goes to the heart of the popular education project: how is agency and knowledge conceived? When activists are intent on exposing people to the right or true knowledge, then they construct those they seek to mobilise as having the wrong kind of knowledge. At the same time, when activist educators are too quickly invested in over-valorising experiential knowledge and essentialising 'expert' knowledges, then what constitutes 'really useful knowledge' becomes attenuated. Drawing on our review of various literatures and first-hand experiences, our argument is that knowledge in social movements is messy, polychrome and dynamic and involves twists and turns around who and what is an expert and what can be learned from science.

Food, Inc. as a social action project conceives of consumers as calculative who either lack agency because they do not have sufficient information and only have agency when they do get the right information. In Food, Inc. there are various characters who eat hamburgers. When cating hamburgers there are 'politically messy' forms of knowledge at play. Of course, we should focus on knowledges about how hamburgers are produced but likewise, knowledges about how they are consumed. The work of Sutton (2001) might get us to think about embodied practices - the possible reasons we buy hamburgers may have something to do with smell, images and memory associations. Short (2006) argues that just because we might use pre-prepared food does not make us unknowledgeable - we have to plan, budget, organise. Laudan (2010) observes that fast-food joints are valued by consumers who want conviviality that is less intimidating than the sort to be found in a café where you may need certain types of cultural capital to feel that you fit in. Miller (2004) has commented on how consumers value the child-friendly nature of fast-food hamburger joints. There are many forms of consumer knowledge being denied and flattened through these caricatures.

In mundane settings, people's political actions are not only inspired by calculations about what will bring about macro change, but also by ideas about the value of 'micro-political and lifestyle-based modes of civic agency and citizenship based around people's personal lives and relations with each other' (Lewis and Potter, 2011: 16). When it comes to shopping, preparing, cooking, eating and clearing up food, personal lives and relations, and the knowledges that permeate all of these are critical. To put it bluntly, we think it is possible to find positive 'agency' and 'knowledges' among consumers who decide to eat fast-food hamburgers. Our point is not simply that 'ordinary people's knowledge' is marginalised but that 'ordinary people's knowledge' is 
plural and comes from different sources and experiences. A task for popular educators is to start recognising multiple forms of knowledges and the contested nature of all knowledges, including so called bottom up and dominant knowledge.

\section{Conclusion}

Our aim has to been to contribute to the growing field of social movement learning by examining notions of knowledges in food activist pedagogy. We are interested in the politics of who is seen to be 'in the know', but also in de-romanticising some forms of marginalised knowledge. It is important to move away from who knowers are to what knowledges are being reproduced in social movements. We are interested in ways to study everyday experience as a site that create knowledge and enables learning and action for social change. And we think that cultural and political struggles around food - after all, we eat food every day - offer ample opportunities to do this. But experience should not simply be seen as unmediated, acultural and therefore, somehow more real or authentic.

Our case study of Food, Inc. shows that it is important to recognise that social movements do not simply generate knowledge but also recycle and transform preexisting knowledges. Even those knowledges that are imagined to be self-evident, 'already known' by theorists, for example science are actually more variegated and contested than is sometimes suggested.

We have discussed how domestic, embodied and women's knowledges are missing in Food, Inc. and in much writing on food social movements. In looking at Food, Inc. we can start to ask what kind of knowledges are privileged and what kinds of politics they produce. As Kimura (2010) has argued it is important that the gendered nature of food making does not lead to women being seen as the problem or the solution in food reform.

Popular educators have theorised about knowledge and drawn heavily on terms coined by Richard Johnson (1979) - 'really useful knowledge' as opposed to merely useful knowledge. We like the notion of 'really useful knowledge' that starts with the experiences and concerns of large numbers of 'ordinary' people. But we are arguing there are various and particular ways to do this. To consolidate our argument in this paper, we consider a final quotation from social movement learning theorists, Scandrett et al who state that:

What engages individuals to act collectively bas little to do with their motivation, identity, 'inner meanings' or awareness of oneself as an autonomous actor ... but rather the violation of one's socially embedded values by the interests and logic of capital accumulation (2010:127).

We take issue with this assertion on two counts. First, it presumes that a certain kind of knowledge - knowledge of the violation of one's interests - is what is needed to mobilise people. It assumes other more subjective ways of knowing are not useful. While we too might problematise categories such as motivation and inner meanings, we do think that there are many forms of subjective knowledge that could be useful when looking at food social movements. Our second issue with this quotation is that it is so sure about which knowledges count, which knowledges move. When it comes to collective action for food there is ambiguity and contestation about what constitutes knowledge, and in particular anti-capitalist knowledge. Realisation of such ambiguity, 
and contestation should not lead to paralysed inaction, but to informed and nuanced action. A question then for popular educators is how we can mobilise social change through a less narrow idea of knowledge and its effects.

\section{Acknowledgements}

We would like to thank Tony Brown, Elaine Lally, Nick Hopwood, and Keiko Yasukawa for their helpful comments. The paper is part of a larger research project funded by Cosmopolitan Civil Societies, UTS, Sydney.

\section{References}

Belasco W.J. (2007) Appetite for change: How the counterculture took on the food industry. Ithaca: Cornell University Press.

Birchall, C. (2006) Knowledge goes pop: From conspiracy theory to gossip. Oxford: Berg.

Chesters, G. and Welsh, I. (2001) Social Movements: The key concepts. London: Routledge.

Choudry, A. and Kapoor, D. (eds.) (2010) Learning from the ground up: Global perspectives on social movements and knowledge production. New York: Palgrave Macmillan.

Clover, D.E., Follen, S. and Hall, B. (2000) The nature of transformation: Environmental adult education. Toronto: Ontario Institute for Studies in Education.

Clover, D.E. and Hall, B. (2000) In Search of social movement learning: The Growing Jobs for Living Project. WALL Working Paper, No 18, Spring. OISE University of Toronto.

Clover, D.E. (2004) (ed.) Global Perspectives on Environmental Adult Education. New York: Peter Lang.

Clover, D.E. and Hall, B. (2009) 'Critique, Create and Act: Environmental Adult and Social Movement Learning in an Era of Climate Change', in F. Kagawa and D. Selby (eds), Education and climate change: Living and learning in interesting times. New York: Routledge.

Collins, E. T. (1993) 'Food adulteration and food safety in Britain in the 19th and early 20th centuries', Food Policy, 18(2), 95-109.

Cook, I. and Crang, P. (1996) 'The world on a plate: Culinary culture, displacement and geographical knowledges', Journal of Material Culture, 1, 131-154.

Cook, S. (2009) 'New spaces and new places: Adult education and the creation of alternative foodscapes', Graduate Food Discussions Paper Series, Ryerson University, Canada, Vol. 1, Fall: 19-31.

Crowther, J., Hemmi, A., Martin, I. and Scandrett, E. (2008) Learning tbrough ICTS in the environmental justice movement: Case studies from Scotland', in: SCUTREA 2008 38th Annual Conference: Whither Adult Education in the Learning Paradigm?, 2-4 July 2008, Edinburgh. (Unpublished).

Crowther, J. and Shaw, M. (1997) 'Social movements and the education of desire', Community Development Journal, 32(3), 266-279.

Csurgo, B.; Kovach, I. and Kucerova, E. (2008) 'Knowledge, power and sustainability in contemporary rural Europe', Sociologia Ruralis, 48@(3), 292-312.

Eyerman, R. and Jamison, A. (1991) Social movements: A cognitive approach. Oxford: Polity Press.

Flowers, R., Boyd, M. and McEwen, C. (eds.) (2003) 'Environmental adult education', Bulletin of Good Practice in Adult and Community Education, 7.

Flowers, R. and Chodkiewicz, A. (2009) 'Developing a more research-oriented and participant-directed learning culture in the Australian environment movement', Australian Journal of Adult Learning, 49/2.

Flowers, R., Guevara, R. and Whelan, J. (2009) 'Popular and informal environmental education: The need for more research in an "emerging" field of practice', Report: Zeitschrift für Weiterbildungsforscbung, 2/2009, 36-50. 
Flowers, R. and Swan, E. (2010) 'Healthy and sustainable food and consumer learning'. Research Proposal: Cosmopolitan Civil Societies Research Centre, UTS, Sydney.

Fonte, M. (2008) 'Knowledge, food and place. A way of producing, a way of knowing', Sociologia Ruralis, 48(3), 200-222.

Franklin, A. (2002) Nature and social theory. Sage: London

Galusky, W. (2010) 'Playing chicken: Technologies of domestication, food, and self', Science as Culture, 19(1), $15-35$.

Goldblatt, D. (2000) Knowledge and the social sciences: Theory, method, practice. London: Routledge.

Goodman, M.K., Boykoff, M.T. and Evered, K.T. (Eds.) (2008) Contentious geograpbies: Environmental knowledge, meaning, scale, pp. 1-23. Aldershot: Ashgate.

Goodman, D. and DuPuis, M. (2002) 'Knowing food and growing food: Beyond the productionconsumption debate in the sociology of agriculture', Sociologia Ruralis, 42(1), 5-22.

Grunert, K. (2005) 'Food quality and safety: consumer perception and demand', European Review Agricultural Economics, 32(3), 369-391.

Guthman, J. (2004) Agrarian dreams: The paradox of organic farming in California. Berkeley: University of California Press.

Hall, B. (2004) 'Towards transformative environmental adult education: lessons from social movement contexts', in Darlene Clover (ed.) Global perspectives on environmental adult education, pp. 152-168. New York: Peter Lang.

Hall, B. (2006). 'Social movement learning: Theorizing a Canadian tradition', in Tara Fenwick, Tom Nesbit and Bruce Spencer (eds.), Contexts of adult education. Canadian perspectives, pp. 230-238. Toronto: Thomson Educational Publishing.

Hall, B. (2009) 'A River of life: Learning and environmental social movements', Interface: A Journal for and about Social Movements 1(1), 46-78.

Hall, B. and Clover, D. (2005) 'Social Movement Learning', in Leona M. English (ed.) International Encyclopedia of Adult Education. New York: Palgrave Macmillan.

Haraway, D. (1996) Modest witness at Second Millennium. FemaleMan meets OncoMouse: Feminism and technoscience. London: Routledge.

Hill, L. and Clover, D. (eds.) (2003) 'Environmental adult education: ecological learning, theory, and practice for socio-environmental change', New Directions for Adult and Continuing liducation, 99. San Francisco: Jossey-Bass.

Hincliffe, S. and Woodward, K. (2004) The natural and the social: Uncertainty, risk, change. London: Routledge.

Iedema, R. (2001) 'Analysing film and television: A social semiotic account of hospital: an unhealthy business', in T. van Leeuwen and C. Jewitt (eds), Handbook of visual analysis. London: Sage.

Jewitt, C. and Oyama, R. (2001). 'Visual meaning: A social semiotic approach', in T. van Leeuwen and C. Jewitt (eds), Handbook of visual analysis, pp.134-156. London: Sage.

Johnson, R. (1979) 'Really useful knowledge', in Working class culture: studies in bistory and theory, J. Clarke, C. Crichter and R. Johnson (eds.), pp. 42-75. London: Hutchinson.

Johnson, R. (1986) 'What is cultural studies anyway? Social Text, 16, 38-80.

Johnston, J. and Baumann, S. (2009) Foodies: Democracy and distinction in the gourmel: foodscape. New York: Taylor and Francis.

Kimura, A. (2010) 'Food education as food literacy: privatised and gendered food knowledge in contemporary Japan', in Agriculture and Human Values,1-18.

Lewis, T, and Potter, E. (2011) Etbical consumption. London: Routledge.

Lindenfeld, L.A. (2010) 'Can documentary food films like Food, Inc. achieve their promise?' Environmental Communication. A Journal of Nature and Culture, 4(3), 378-386.

Malone, K. (2003a) 'Participatory research and adult environmental education', Bulletin of Good Practice in Adult and Community Education, 7, 4-9.

Malone, K. (2003b) 'Critical environmental adult education: Taking on the environmental challenge', in D. Clover (ed.) Global perspectives in environmental adult education. New York: Peter Lang. 
Miller, D. (2004) 'How infants grow mothers in North London', in J.S. Taylor, and D.F. Wozniak (eds.), Consuming motherbood, pp. 31-51. New Brunswick: Rutgers University Press.

Myerson, G. (2000) Donna Haraway and GM foods. Sleaford: Icon Books.

Nisbet, M. and Aufderheide, P. (2009) 'Documentary film: towards a research agenda on forms, functions and impacts', Mass Communication and Society, 12(4), 450-456.

Nolan, B. (2011) 'Representation and ideology in film.1' University of Wisconsin, accessed 13 September 2011.

Pollan, M. (2006) The omnivore's dilemma: A natural history of four meals. London: Penguin.

Ramsey, J.G. (2010) 'Rattling the capitalist food chain', in The Minnesota Review. Fall 2009-Spring 2010: 255-262.

Rose, G. (2007) Visual methodologies: An introduction to the interpretation of visual materials. London: Sage.

Ross, A. (1991) Strange weather: Culture, science, and technology in the age of limits. Verso: London.

SafeFoodInc.com. (accessed 13 September2011) http://www.safefoodinc.org/ .

Sandlin, J. and Walther, C. (2009) 'Complicated simplicity: Moral identity formation and social movement learning in the Voluntary Simplicity movement', Adult Education Quarterly, 59(4), 298-317.

Scandrett, E., Crowther, J., Hemmi, A., Mukherjee, S., Shah, D., and Sen, T. (2010) 'Theorising education and learning in social movements: environmental justice campaigns in Scotland and India', Studies in the Education of Adults, 42(2), 124-140.

Schlosser, E. (2001) Fast food nation: The dark side of the All-American meal. New York: Harper Perennial.

Short, F. (2006) Kitchen secrets: The meaning of cooking everyday life. Oxford: Berg Publishers.

Soper, K. (1995) What is nature? Culture, politics and the non-buman. Oxford: Wiley-Blackwell.

Sturken, M. and Cartwright, L. (2001) Practices of looking: An introduction to visual culture. Oxford: Oxford University Press.

Sutton, D. (2001) Remembrance of repasts: An antbropology of food and memory. New York: Berg Publishing.

Swan, E. (2010) 'Commodity diversity: Smiling faces as a strategy of containment,' Organization, $17(1), 77-100$.

van Leeuwen, T. (2001) 'Semiotics and iconography', in T. van Leeuwen and C. Jewitt (eds), Handbook of visual analysis. London: Sage.

Vileisis, A. (2004) Kitchen literacy: bow we lost knowledge of where food comes from and why we need to get it back. Connecticut: Island Press.

Walters, S. (2005) 'Social movements, class and adult education', New Directions for Adult and Continuing Education, 106, 53-62.

Weingart, P., Muhl, C. and Pansegrau, P. (2003) 'Of power maniacs and unethical geniuses: science and scientists in fiction film', Public Understanding of Science, 12, 279.

Whiteman, D. (2010) 'Documentary Film as Policy Analysis: The impact of "Yes, In My Backyard" on activists, agendas, and policy', Mass Communication and Society, 12, 457-477. 
Copyright of Studies in the Education of Adults is the property of National Institute of Adult Continuing Education and its content may not be copied or emailed to multiple sites or posted to a listserv without the copyright holder's express written permission. However, users may print, download, or email articles for individual use. 